\title{
Overview of Community-Based Crowdfunding in Malaysia: Legal Issues and the Way Forward
}

Rozita Othman, Zuraidah Ali, Ibtisam @ Ilyana Ilias, Azlena Khalid

To Link this Article: http://dx.doi.org/10.6007/IJARBSS/v11-i11/11306 DOI:10.6007/IJARBSS/v11-i11/11306

Received: 04 September 2021, Revised: 06 October 2021, Accepted: 27 October 2021

Published Online: 17 November 2021

In-Text Citation: (Othman et al., 2021)

To Cite this Article: Othman, R., Ali, Z., Ilias, I. @ I., \& Khalid, A. (2021). Overview of Community-Based Crowdfunding in Malaysia: Legal Issues and the Way Forward. International Journal of Academic Research in Business and Social Sciences, 11(11), 1213-1224.

Copyright: @ 2021 The Author(s)

Published by Human Resource Management Academic Research Society (www.hrmars.com)

This article is published under the Creative Commons Attribution (CC BY 4.0) license. Anyone may reproduce, distribute, translate and create derivative works of this article (for both commercial and non-commercial purposes), subject to full attribution to the original publication and authors. The full terms of this license may be seen at: http://creativecommons.org/licences/by/4.0/legalcode

Vol. 11, No. 11, 2021, Pg. $1213-1224$

Full Terms \& Conditions of access and use can be found at http://hrmars.com/index.php/pages/detail/publication-ethics 


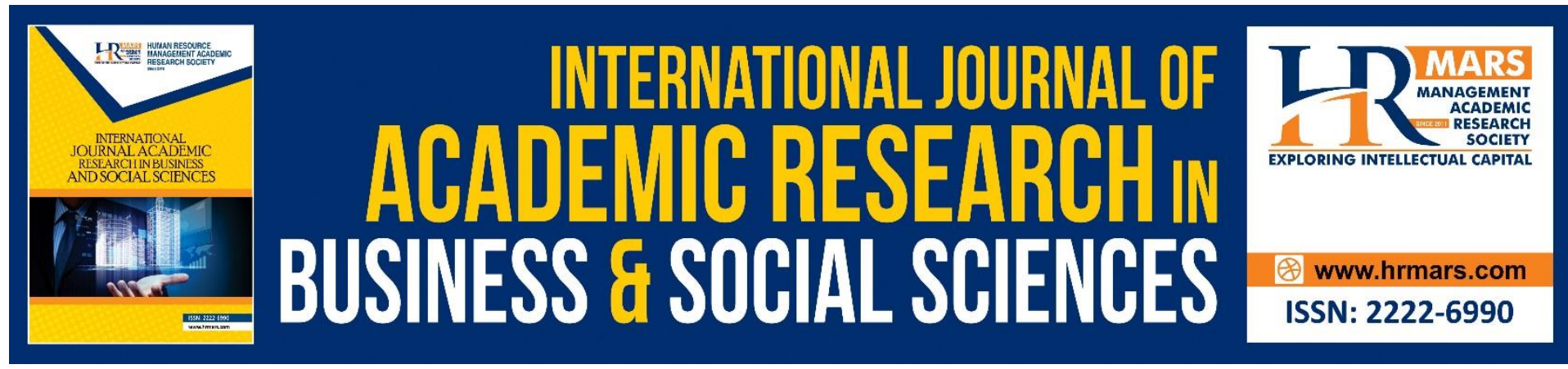

\title{
Overview of Community-Based Crowdfunding in Malaysia: Legal Issues and the Way Forward
}

\author{
Rozita Othman ${ }^{1}$, Zuraidah Ali², Ibtisam @ Ilyana llias ${ }^{3}$, Azlena \\ Khalid ${ }^{4}$ \\ 1,3,4 Universiti Teknologi MARA, ${ }^{2}$ International Islamic University Malaysia \\ Correspondence Email: rozita876@uitm.edu.my
}

\begin{abstract}
The primary objective of this study is to evaluate community-based crowdfunding activities in Malaysia with a particular focus on the prevalent issues and existing legal framework. While the objective of crowdfunding is benevolent, there are, however, unscrupulous individuals or entities which take advantage of the public's generosity for their illegitimate gain. Adopting content analysis, both primary and secondary sources of law were evaluated. These include journal articles, conference proceedings, thesis, books and chapters in books. The sources are accessible from google scholars and online databases such as Elsevier, HeinOnline and LexisNexis. The finding of the study discloses that the core obstacles in community-based crowdfunding in Malaysia are threefold namely the problem of trust, conflict of interest and accountability, the issue of fraud and the lack of proper regulation. Thus, this study proposes some recommendations to improve the legal position governing crowdfunding in Malaysia, including setting up a flexible licensing regime and conducting a periodical inspection on the crowdfunding campaigns. This study is significant in highlighting the widespread problems associated with crowdfunding in Malaysia and the way forward which can be adopted by the relevant regulators to enhance the current legal framework. Eventually, it will preserve public confidence and protect society from fraudulent activities by irresponsible individuals or organisations.
\end{abstract}

Keywords: Community-Based Crowdfunding, Charity, Trust, Fraud, Donation.

\section{Introduction}

Donation is one of the charity activities that is not strange to the Malaysian population. Charity activities cannot be separated from human beings generally. The practice of raising contributions for charity has long been prevalent in the Malaysian community, and the internet and technological advancements have expanded today's solicitation. The majority of these collections are made by registered companies. Nevertheless, some may be carried out by unlicensed individuals (Abdullah, 2016).

Donation-based crowdfunding is the most popular type of community-based crowdfunding. In donation-based crowdfunding, the donors do not expect reimbursements such as products, gifts, or rewards. The person in charge of donation-based crowdfunding will be thankful to the donors who contribute to the fund (Lee et al., 2019). Donation-based crowdfunding is 
more traditional than reward-based, equity-based, and lending-based crowdfunding. The donors are generally aware of the purpose of their donation and willing to contribute more (Abdullah \& Bakri, 2021). The primary purpose is to contribute and benefit the public, for instance, to help the poor, those affected by disasters, building mosques, religious schools or even for personal benefit such as paying hospital bills and providing food for needy families. Despite its many advantages, research has shown that crowdfunding is vulnerable to a number of dangers, including default, platform shutdown or failure, fraudulent conduct by parties engaged, illiquidity, cyber-attacks, and a lack of openness and disclosure. Abdullah (2016) discovered that crowdfunding campaigns are plagued by six difficulties in general. First, if the campaign fails to accomplish its objectives or attract public attention, its reputation will be jeopardised. Second, the issuer seeking the funds has no intellectual property (IP) protection because his idea is liable to be replicated once it is put on the platform. Third, the donors' tiredness. Fourth, many jurisdictions lack an adequate regulatory framework. Fifth, there is a lack of due diligence in investment choice procedures, and sixth, there is a lack of a formal approach. As far as the issue on reputation is concerned, Ahmad Mohamad et al (2020) highlighted two websites for charity platforms in Malaysia that are more to a personal fundraising platform, namely generosity.com and Indiegogo.com. These websites allow people to donate to needy people, charity funds, and public-benefit projects such as the construction of overhead bridges and schools. They said that donation-seeking crowdfunding initiatives in Malaysia have proven to be ineffective. Fundraising for Refugee Aid in Malaysia, which has only earned US\$10 (RM39) in two months, is one of the efforts that has failed to gain traction.

To further understand community-based crowdfunding, this paper will discuss the definition of crowdfunding on a broader scope and the types of crowdfunding in Malaysia. The challenges faced, and the legal implication will then be discussed to suggest the appropriate legal framework for community-based crowdfunding activities in Malaysia.

\section{Definition of Crowdfunding}

Crowdfunding has been touted as a potential new source of capital. Crowdfunding began as a way for people to share their ideas with others. It introduces a concept to a broad and anonymous audience to receive funding from them. Sometimes it is also known as "crowdsourcing". According to Lutfi \& Ismail (2016), crowdfunding is a response to an open request in which a large group of people voluntarily opt to support a goal directly. Typically, each person who wants to help achieve a specific goal contributes a small amount of money in exchange for a profit or a product or service to be produced. Individuals sometimes give out of the goodness of their hearts without expecting anything in return. Crowdfunding is well suited to the notion of microfinance because it is funded by minor contributions from a large number of people.

Another perspective of defining crowdfunding in tandem with technological evolution is a type of participative online activity in which an individual, institution, non-profit organisation or company propose to a group of individuals of varying knowledge, heterogeneity and number via a flexible open call to voluntary undertake a task which always entails mutual benefit (Zahari and Azmi, 2019). In short, the definition denotes three crucial elements of crowdfunding: technology, capital funding, and the power of the crowd. These three essential elements enable many small efforts to accumulate a substantial financial outcome. Moreover, they contended that donation through crowdfunding is beneficial to society because it can 
raise much money within a short period. Thus, it would provide adequate and timely support to help seekers, in many cases, save their lives.

Despite various definitions of crowdfunding, Mohamad et al (2020) believe that it originated from crowdsourcing, where "the act of doing a job traditionally by a designated agent (an employee) and outsourcing it to an undefined, generally large group of people in the form of an open call". The distinction between crowdsourcing and crowdfunding is that crowdsourcing focuses on information and consumer preferences. However, crowdfunding can be used for various reasons, including those seeking financial assistance, donation purposes, or disaster relief. The crowd could be made up of people from all around the world interested in sponsoring projects or participating in campaign events. Crowdfunding has evolved based on two key categories: community-based crowdfunding and financial return crowdfunding (Abdullah, 2016). Donation-based and reward-based crowdfunding are two types of community-based crowdfunding, whereas financial return crowdfunding can be peer-to-peer (P2P) lending or equity crowdfunding.

\section{Types of Crowdfunding}

Crowdfunding can be categorised into four types: donation-based, reward-based, equitybased, and lending or debt-based (Freitas \& Amado, 2013).

1. Donation-based - Donations are usually gathered and maintained for a specific purpose. Those who contribute the money are more likely to donate higher amounts per person since they know their money will be used for a specific project. These types of funders are also more likely to remain loyal over time. Funders' primary motivation is social, and it is intrinsic, which is generally a solid foundation for a long-term donor relationship.

2. Reward-Based - Project owners who would like to accumulate donations for a certain project may use this business model in exchange for some non-monetary rewards. The incentives have a symbolic worth that is typically far lower than the amount donated. Furthermore, a reward in this situation cannot be considered a show of gratitude. The parties generally agree that providing goods is not a legally binding obligation and that the transaction is not a sale.

3. Lending-Based Crowdfunding - Lending-based crowdfunding involves borrowing money from a group of people rather than a bank. The role of the platform can vary; some platforms will act as an intermediary and will also make repayments to lenders, whereas others will merely act as matchmakers, and the borrower and lenders will be connected only the transaction is set in stone.

4. Equity-based - When a firm seeks finance from a group of people rather than a business angel or another private investor, this is referred to as equity crowdfunding or crowd investing. Some funders are particularly interested in projects that share their beliefs, are locally engaging, or provide job possibilities in their neighbourhood (Sharif et al., 2018). Others thoroughly understand the market, project, or firm in question and wish to contribute finances and experience to the initiative's success. This is extremely similar to the practice of business angels. Equity crowdfunding also covers equity-like arrangements in which the "funder" is only a creditor with a contractual right to get the same compensation as equity (shares), and where the "funder" is merely a creditor with a contractual right to receive that payoff (Abdullah \& Bakri, 2021). 


\section{Various Models of Crowdfunding Strategies}

From another point of view, the literature suggests that parties involved in crowdfunding activities have come out with crowdfunding strategies. Based on those four types of crowdfunding, there are three most common models of crowdfunding strategies that can be found, which are:

i. The Donation Model

ii. The Lending Model

iii. The Investment Model

Individuals who make a financial donation to a project without expecting a financial return use the Donation Model. Donation-based projects and platforms frequently implement a reward or incentive system to encourage donations, in which contributors are recognised for their support with a small reward. Individuals give money to a project in the Lending Model with the hope that it will be reimbursed. Meanwhile, the Investment Model is similar to a traditional equity investment, in which a person receives equity in a company in exchange for funding (Lau \& Chew, 2016).

This paper will focus on the first type of crowdfunding, donation-based crowdfunding, and the model of crowdfunding strategies is the donation model. Donation-based crowdfunding is ranged under Community-Based Crowdfunding. It can be perceived exactly as it sounds; the operation accumulates and allocates the amount of donation that does not expect any kind of value in return. It is all about the expression of satisfaction from the donors on what they believe in. The major goal of this platform is to help a social cause while also benefiting the general public through donations. As a result, the sole return for the donors will be gratitude and the fulfilment of a social duty obligation. In exchange for the funds collected, no shares or other physical rewards will be issued. It is commonly apparent that donation-based crowdfunding is raised for non-profit causes (Mohamad et al., 2020).

\section{Overview of Community-Based Crowdfunding in Malaysia}

Malaysia's crowdfunding business is still in its early stages of development (Mohd Zahari \& Nik Azmi, 2019). According to the Asian Institute of Finance (2014), public knowledge and willingness to participate in donation-based crowdfunding are low. In terms of the donation's objective, Malaysians are adamant that the monies would be used to assist the community in generating funds, reducing poverty, and providing assistance to homeless people and others in need. This is reflected in the World Giving Index 2015, which ranks Malaysia as the tenth most generous country among 145 countries.

In terms of the donation's objective, Lehner (2013) claimed that donation-based crowdfunding has long been a well-established method of funding non-profit ideas and projects. The finest and most prevalent example would be educational campaigns in which sponsors are not rewarded in any way. Skolafund is one of the most popular third-party platforms among Malaysian higher education students (Sabarudin et al., 2021). Lutfi \& Ismail (2016) presented another example in the context of health treatment. They claimed that health care is one of the needs covered by daruriyat (essential of life). Poverty has been shown to have a substantial relationship with health care in the majority of cases. Both are concerned with the preservation of human life. Eventually, the low level of life has made it impossible for the poor and needy to obtain health treatment. As a result, they believe that the correct system for donation-based crowdfunding should be able to meet the needs of improving health, alleviating poverty, and improving income distribution. 
Zahari and Azmi (2019) argued that the anticipated usefulness of the technology, as well as the seeming ease of use of the technology, could be factors of public willingness to participate in donation-based crowdfunding. They contended that the more benefits the technology could provide to the public, the they are more likely to participate in donation-based crowdfunding. Furthermore, if the public finds the technology user-friendly, they will use it more often, resulting in more donation-based crowdfunding. They also found that public participation in donation-based crowdfunding is also influenced by three other factors, namely, attitude, subjective norms, and perceived behavioural control. Finally, according to the researchers, an individual's attitude, social pressure on giving, and the ease or difficulty of donating are all factors that can influence the public's willingness to participate in donation-based crowdfunding.

Since Malaysia's population is predominantly Muslim, there is an Islamic-based approach known as Saqadah-Based Crowdfunding that can be categorised as Community-Based Crowdfunding. It incorporates the concept of microfinance for entrepreneurs. Sadaqah (donation) is a dynamic form of philanthropy that differs from zakah (alms-giving) and waqaf (specific obligation of giving a portion of an individual's wealth and possessions for primarily charitable purposes). Unlike sadaqah, zakah is set up to be used for a particular group, whereas waqaf has the feature that its assets should be eternal and inalienable. Sadaqah's qualities allow it to accommodate any proposal to benefit its assets without any Shariahimposed constraints. The contract will be a qard al-hasan (beneficent loan), and no interest will be charged. The administration costs will be covered by public charity money, and the fee will be levied as a flat sum rather than a percentage rate. However, they argue that a suitable platform is required for this paradigm to be implemented.

Furthermore, when it comes to Islamic-Based Crowdfunding, Lutfi and Ismail (2016) indicated that it will be used as a platform to ensure human survival. Their development began with human wants, which may be divided into three categories: first, daruriyat, the essentials of life, second, the necessities that are considered complements or hajiyat (improvements), and third, tahsiniyat (the needs that provide people with social status or recognition). Daruriyat, is connected with five goals that are so important in and of themselves that people cannot live without them, and losing them poses a threat to the survival of regular order. The goals are preserving religion, human life, nasab (family lineage), materials, and mind. These must be safeguarded in order for someone to have a normal life. To summarise, donation-based crowdfunding has benefited society at large. It has been proven as one of the platforms that bring welfare and comfort to the human being as a whole, particularly to Malaysians.

\section{Issues and Challenges in Community-Based Crowdfunding in Malaysia}

This section examines critical issues and challenges surrounding community-based crowdfunding in Malaysia which are divided into three primary categories: trust, conflict of interest and accountability, fraud, and lack of proper regulation.

\section{Trust, Conflict of Interest and Accountability}

Trust is a crucial human attribute that places faith in an individual's or an institution's integrity, reliability, and fairness. The social and economic environment of society is motivated by trust. In social interactions, trust is vital, particularly in the early stages or to preserve a reputation-based connection. Because social indications to indicate specific risks are lacking when it comes to technology like the internet, trust becomes a significant issue (Nor \& Hashim, 2020). 
Trust is thought to be a critical aspect between a seller and a buyer in the commercial world, and the same can be stated for crowdfunding. The fundraiser must have a funder's trust. The connection between the project owner (fundraiser) and the funder through reward-based crowdfunding will built trust between them, resulting in increased sponsorship, emotional bonds, and social identifications. Additional research on religion and consumer trust shows how religion and consumer trust influence consumer behaviour, particularly in terms of material, intolerance, ethics, and risk aversion (Agarwala et al., 2019). As such, trust is proven to be a vital element in crowdfunding. Should there be no trust, the fundraisers can collect no money from the donors or the society as a whole.

Conflicts of interest are another crucial circumstance in which an element of trust can be perceived. Both owners or individual financing providers may engage in conflicts of interest when using confidential information to create a higher profit. These circumstances must be avoided at all costs, and laws for internet crowdfunding should be appropriately enforced (Abdullah \& Bakri, 2020).

Trust and conflict of interest lead to issues on accountability. The accountability of fundraisers, especially the Non-Profit Organisations (NPOs), relates to Functional Expenses Reporting (FER) as a mechanism of disclosure. The disclosure practices by NPOs could be sharpened by disclosing a good quality of information. The absence of best practices concerning accountability increases various risk exposures to NPOs, including fraud risk. Moreover, the lack of good quality public mechanisms of accountability resulted in the interruption of the potentially more effective private mechanisms in building trust (Bakar et al., 2019).

\section{Fraud Cases in Crowdfunding}

Another prominent issue in crowdfunding, according to Saiti et al., (2018), are fraud cases and scams. Since crowdfunding is built on trust, it is very challenging to maintain trust if fraud occurs. They cited the example of the most well-known crowdfunding fraud that occurred in the US, involving an oil and gas company named Ascenergy that raised USD 5 million from crowdfunding platforms. Almost USD 1.2 million of that was spent by the founders on nonbusiness materials and payments to other companies.

In Malaysia, even though crowdfunding brings many benefits to organisations and society in general, some impediments make the initiative prone to failure. Moreover, Abdullah and Bakri (2020) discovered that the existing crowdfunding technique has some flaws that need to be addressed right away. One of the items on the list was a fraud. The potential for fundraisers to use crowdfunding sites to fund scams is exceptionally significant. Since crowdfunding is different from venture finance, where the pool of donors has no personal contact or knowledge of the business concept, nor the idea beyond what is offered on the crowdfunding website, the danger of fraud grows. As a result, they stressed the need for fraud prevention and detection in safeguarding the industry's integrity and ethics.

Lau and Chew (2016) shared the same view on fraud in crowdfunding. They are of the opinion that fraud is the most critical challenge that is constantly being faced by crowdfunding. In their findings, they found that a majority of the respondents are not confident in crowdfunding because they are not sure whether the agent who receives the fund can be trusted or not. Fraud always happens to the trusted person, who is a fundraiser. Sadly, it is a trusted person that quickly turns out to be a trust violator. The writers also agreed with the hypothesis developed by Cressey, whereby "trusted persons become trust violators when they conceive of themselves as having a financial problem which is non-shareable, are aware 
this problem can be secretly resolved by violation of the position of financial trust and can apply to their conduct in that situation verbalisations which enable them to adjust their conceptions of themselves as trusted persons with their conceptions of themselves as users of the entrusted funds or property".

\section{Lack of Proper Regulation}

In many jurisdictions, including Malaysia, the laws and rules for community-based crowdfunding, particularly donation-based crowdfunding, are still unclear (Abdullah, 2016). In donation-based crowdfunding, the sponsors of donors are funded with "no return". However, there is also the situation where the fundraiser promised to return by compliments such as the products that will be developed or a "Thank you" card. Lee et al., (2019) contended that donation-based crowdfunding platforms function as an unregulated open market where there is less intervention in the process of raising funds.

Likewise, for Islamic crowdfunding, Saiti et al (2018) found a similar problem where it faces many challenges to compete with the current crowdfunding system. This is because the regulators are more concerned with the majority of industry groups. For instance, Malaysia regulates the crowdfunding business as a second-class operator in the market by limiting the funds raised and the fundraiser.

Abdullah (2016) argued that the legislation and regulations governing the solicitation of funds for donation-based and reward-based crowdfunding are still in flux. She compared it to other jurisdictions that require charity collections by any entity, such as trustees or non-profit organisations, to be registered. According to the author, starting January 1, 2016, any fundraiser entity wishing to collect charitable donations from the general public in California must register with the state. Explaining community-based crowdfunding as non-equity crowdfunding, which includes donations for disaster relief and personal medical pleas, Hong (2018) found that there is currently no registration required for this type of crowdfunding. They are not fully regulated; in fact, there are no laws in Malaysia governing such organisations. Therefore, he emphasised that there is a need for non-equity crowdfunding to be regulated.

\section{Law and Regulation on Crowdfunding in Malaysia}

This section will examine the applicable laws and regulations on crowdfunding in Malaysia and analyse whether there is any inadequacy of law and regulation pertaining to the same. Charities and benevolent institutions are governed by the federal government. This is provided for in pursuant to Article 74, Ninth Schedule, Federal List (List I), Item 15(c) of the Federal Constitution. As a result, the federal government regulates public charities that accept donations from the public regardless of the contributors' religion (Abdullah, 2016).

As such, there are few regulations involved pertaining to crowdfunding at the federal level. The regulations and applicable legal requirements vary since the fundraisers are not similar. Therefore, there are few legislation governing Non-Profit Organisations (NPOs), and each of them has different legal requirements. Bakar et al (2019) listed the legal requirement and the regulatory bodies involved. They found that the registration of society is governed by the Societies Act 1966 (Act 335). The requirement is only to prepare the statement of receipts and payments and the balance sheet. Meanwhile, the Inland Revenue Department (IRD), under section 44(6) Income Tax Act 1967, only requires audited financial statements for taxexemption purposes from these organisations. The Legal Department of the Prime Minister's 
Department (BHEUU) imposed a similar requirement. The summary of regulatory requirements for NPOs in Malaysia is depicted in Table 1 below: -

Table 1

Regulatory Requirement for NPOs in Malaysia

\begin{tabular}{|l|l|l|}
\hline \multicolumn{1}{|c|}{ Governing Body } & \multicolumn{1}{|c|}{ Governing Provisions } & \multicolumn{1}{|c|}{$\begin{array}{c}\text { Document Required } \\
\text { (Financial Statements) }\end{array}$} \\
\hline Registry of Society (ROS) & $\begin{array}{l}\text { 1966: Societies Act (Act 335) } \\
\text { and Regulations [Section } \\
\text { 14(d)] Form 9 }\end{array}$ & $\begin{array}{l}\text { Statement of receipts and } \\
\text { payments and the balance } \\
\text { sheet }\end{array}$ \\
\hline $\begin{array}{l}\text { Inland Revenue Department } \\
\text { (IRD) for tax-exempt status }\end{array}$ & $\begin{array}{l}\text { Income Tax Act 1967 } \\
\text { [Section 44(6)] }\end{array}$ & $\begin{array}{l}\text { Audited Financial } \\
\text { Statements }\end{array}$ \\
\hline $\begin{array}{l}\text { Legal Department, Prime } \\
\text { Minister's Department }\end{array}$ & Not available & $\begin{array}{l}\text { Audited Financial } \\
\text { Statements Functional }\end{array}$ \\
\hline
\end{tabular}

Source : Bakar, Tajuddin, and Karim 2019

From the above table, it can be summarised that there is no specific standard requirement for NPOs financial statements. Furthermore, there is also no legal requirement for NPOs in Malaysia to disclose their financial statements to the public. This weakness clearly shows that a sound monitoring system is not there to smell any fraud that might occur. As discussed earlier, most fraud cases happen in crowdfunding activities, and they involve a trusted person. Undeniably, the issue of accountability relating to NPOs in Malaysia crucial. Moreover, NPOs also have social obligations towards the donors. Disclosure statements and reports are among the most widely used tools of accountability and are required by federal or state laws in many countries (Bagheri et al., 2019). The lack of regulatory requirements or best practices concerning accountability increases various risk exposures to NPOs, including the risk of fraud. As such, the absence of good quality public mechanisms of accountability inhibits the impact of the potentially more effective private mechanisms in building trust (Bakar et al., 2019). Furthermore, other legal issues arise comprise the absence of simple licensing process, the absence of criterions for crowdfunding platforms either Community-Based Crowdfunding or Shariah-Based Crowdfunding, no incentives to donors as well as lack of monitoring on the crowdfunding campaigns. The similar issues highlighted also occur in respect of Shariahbased crowdfunding. Hence, it is clear that the current Malaysian regulatory framework has flaws. Thus, it is advisable to suggest appropriate regulatory changes to fit the rapidly expanding crowdfunding industry (Abdullah, 2016).

\section{Recommendations and Way Forward}

This part will discuss the recommendation and suggestions for the regulatory rules governing crowdfunding in the near future. It is suggested that the Income Tax Act 1967 to establish specific standard requirement for NPOs' financial statements. The law should also make it mandatory for NPOs in Malaysia to disclose their financial statements to the public. Noncompliance must entail strict punishment. 
To ensure the smooth operation of crowdfunding, Lutfi et al (2016) advised that policymakers should make the process of getting a licence for a crowdfunding platform as simple as possible, with reasonable prices. They also recommend that the Malaysian Security Commission (SC) establish particular criteria for crowdfunding platforms, whether for Community-Based Crowdfunding or Shariah-Based Crowdfunding, where they must be tightly monitored. Another option is for legislators to establish a specific trust fund for crowdfunding. The authors proposed that the government grant tax exemption to donors as an incentive. Meanwhile, Rahman et al (2016) listed down the weaknesses in crowdfunding, including administrative, governance and accounting challenges, lack of advice or handholding from funders, theft of ideas, weak investor protection, and potential for fraud. They also identified that current legal restrictions and the risky nature of small businesses as threats. As such, Saiti et al (2018), suggested that the regulators should introduce regulations for crowdfunding to make periodic checks on the campaigns offered to the public. Crowdfunding can also create an open discussion on the platform for the donors to produce a transparent investment system.

As far as Shariah-based crowdfunding is concerned, Saiti et al (2018) found that one of the strengths of Islamic financial institutions is the existence of Shariah members. This strength has a significant influence on the public because all solutions are derived from Shariah principles. The presence of Shariah members in Shariah-based crowdfunding can make the platform more interactive with distinct engaging interactions. However, the writers found a similar problem faced by Shariah-based crowdfunding regarding issues on regulations. This is because the regulators are more concerned with the majority of industry groups. For instance, Malaysia regulates the crowdfunding business as a second-class operator in the market by limiting the funds raised and the fundraiser. It is submitted that there should be regulation to support both banking and crowdfunding groups and combine the expertise in technology and financing business.

\section{Conclusion}

The preceding discussions reveal that crowdfunding has undeniable potential as a means of obtaining funds for both financial and humanitarian concerns. Parallel with the first objective of this study, the finding discloses three fundamental issues and challenges surrounding crowdfunding activities in Malaysia which are interrelated to each other. Firstly, trust is essential to ensure the success of crowdfunding. Nevertheless, crowdfunding activities are prone to misuse of public trust by fundraisers due to the presence of a conflict of interest and the absence of best practices governing accountability. Secondly, the risk of fraud is apparent particularly due the fact that the donors have no detailed knowledge about the fundraisers. Thus, scammers can consider this platform as one way to conduct scamming activities. Thirdly, the study also finds that currently, there is no proper regulation to regulate crowdfunding in Malaysia. As far as the second objective to assess the existing legal framework governing crowdfunding in Malaysia is concerned, the finding reveals the presence of laws and bodies to regulate NPOs in Malaysia. The registration of a society is governed by the Societies Act 1966, which is under the jurisdiction of the Registrar of Society. The Income Tax Act 1967, which is under the purview of the Inland Revenue Department only requires audited financial statements for tax-exemption purposes from these organisations. Likewise, the Legal Department of the Prime Minister's Department imposed a similar requirement. Nevertheless, the shortcomings of the presence laws are evidenced since there is no specific standard requirement for NPOs financial statements. Secondly, there is no legal 
requirement for NPOs in Malaysia to disclose their financial statements to the public. This flaw plainly demonstrates that there is no sound monitoring system in place to detect any potential fraud. To further enhance the existing legal framework governing crowdfunding in Malaysia, this study proposes some recommendations including establishing specific standard requirement for NPOs' financial statements, mandatory disclosure of NPO's financial statements to the public with harsh punishment for non-compliance, establishing particular criteria for crowdfunding platforms whether for Community-Based Crowdfunding or ShariahBased Crowdfunding with stringent monitoring by SC, establishing a specific trust fund for crowdfunding, provision of tax exemption to donors as an incentive and periodical inspection on the campaigns offered to the public. The similar regulation should be imposed to all types of crowdfunding whether Community-Based Crowdfunding or Shariah-Based Crowdfunding. It is hoped that the recommendations will improve the current legal framework governing crowdfunding in Malaysia and resolve the primary issues of misuse of trust, absence of public disclosure and lack of accountability. This measure will consequently facilitate the crowdfunding activities as well as increase public confidence to donate and contribute.

\section{Acknowledgement}

This work was supported by the Faculty of Law, Universiti Teknologi MARA via Lex Praesta Research Grant; Project ID: 600-TNCPI 5/3/DDF (FUU)(004/2020)

\section{References}

Abdullah, A. (2016). Crowdfunding as an Emerging Fundraising Tool: With Special Reference to the Malaysian Regulatory Framework. Islam and Civilisational Renewal, 7(1), 98-119. https://doi.org/10.12816/0027170

Abdullah, M. R. Y., \& Bakri, M. H. (2020). Determinants of Crowdfunding Acceptance for Maintenance of School Facilities. PalArch's Journal of Archaeology of Egypt / Egyptology, 17(7), 4561-4577. PalArch's Journal of Archaeology of Egypt / Egyptology

Abdullah, M. R. Y., \& Bakri, M. H. (2021). Acceptance of Public towards Crowdfunding for Maintenance of School Property. Estudios de Economia Aplicada, 39(4), 1-14. https://doi.org/10.25115/eea.v39i4.4575

Agarwala, R., Mishra, P., \& Singh, R. (2019). Religiosity and consumer behavior: a summarising review. Journal of Management, Spirituality and Religion, 16(1), 32-54. https://doi.org/10.1080/14766086.2018.1495098

Mohamad, A. K., Nor, M. R., \& Kamely, A. (2020). Crowdfunding: New Form of Both Investment Opportunities and Source of Capital. In Advances in Finance, Accounting, and (AFAE) Book Series (Issue January, pp. 110-135). IGI Global, Business Science Reference. https://doi.org/10.4018/978-1-7998-3257-7.ch012

Bagheri, A., Chitsazan, H., \& Ebrahimi, A. (2019). Crowdfunding motivations: A focus on donors' perspectives. Technological Forecasting and Social Change, 146(June), 218-232. https://doi.org/10.1016/j.techfore.2019.05.002

Bakar, N. R. A., Tajuddin, T. S., \& Karim, N. A. (2019). Functional Expense Reporting Practice Among Non-Profit Organisations (NPOs) Noor. IPN Journal of Research and Practice in Public Sector Accounting and Management, 9(1), 67-84.

Freitas, J. C. De, \& Amado, M. (2013). Crowdfunding in urban planning: Opportunities and Obstacles. At Home on the Housing Market: RC43 Conference Book of Proceedings, February. $\quad$ http://rc43-conference.uva.nl/binaries/content/assets/subsites/rc43conference.uva.nl/rc43-papers/freitas--armado.pdf 
Hong, L. C. (2018). Crowdfunding: Issues Pertaining to Financial Reporting and Assurance in Malaysia. Journal of Wealth Management \& Financial Planning, Volume 5, 17-24. https://mfpc.org.my/wpcontent/uploads/2019/03/OriginalResearchCrowdfunding.pdf

Lau, K. L., \& Chew, B. C. (2016). Crowdfunding for research: A case study in research management centre in Malaysia. International Journal of Industrial Engineering and Management, 7(3), 117-124.

Lee, A. S. G., Chan, K. X., Sum, J. Y., Tan, S. Y., \& Wong, Y. Y. (2019). The Determinants for Successful Crowdfunding in Malaysia (Issue August).

Lehner, O. M. (2013). Crowdfunding Social Ventures: A Model and Research Agenda. Venture Capital, 15(4), 289-311. https://doi.org/10.1080/13691066.2013.782624

Lutfi, M. A., \& Ismail, M. A. (2016). Sadaqah- Based Crowdfunding Model for Microfinancing and Health Care. Journal of Muamalat and Islamic Finance Research, 13(2), 31-51.

Sharif, M. S., Ahamat, A., Abdullah, M., Jabar, J., \& Bakri, M. H. (2018). University Intellectual Property Commercialization: A Critical Review of Literature. Turkish Online Journal of Design Art and Communication, 8(SEPT), 874-886. https://doi.org/10.7456/1080sse/124

Nor, M. S., \& Hashim, N. A. (2020). Trust motivates funders to participate in Shari'ah crowdfunding. Malaysian Journal of Society and Space, 16(2), 228-238. https://doi.org/10.17576/geo-2020-1602-18

Zahari, M. N. H., \& Azmi, N. N. (2019). Determinants Of Public Involvement in Donation-Based Crowdfunding. International Journal of Business and Technology Management, 1(1), 60-70.

Sabarudin, N. A., Alma'amun, S., \& Ahmad, R. (2021). Analysing Educational Campaign's Outcome in Donation-Based Crowdfunding: Social Capital. International Journal of Business and Society, 22(2), 862-880.

Saiti, B., Musito, M. H., \& YUCEL, E. (2018). Islamic Crowdfunding: Fundamentals, Developments and Challenges Challenges and Impacts of Religious Endowments on Global Economics and Finance View project Transparency of Islamic and conventional banks View project. International Journal of Business and Management, 16(January 2020),

$1-18$. https://www.febelfin.be/sites/default/files/InDepth/the_rise_of_crowdfunding.pdf\%0 Ahttps://www.researchgate.net/publication/331408070\%0Ahttps://www.ulster.ac.uk /_data/assets/pdf_file/0009/168417/crowdfunding.pdf 